\title{
Pinking in White Wines - A Review
}

\author{
A.P. $\mathrm{Nel}^{1 *}$, W.J. du Toit ${ }^{2}$, F.P. van Jaarsveld ${ }^{3}$ \\ (1) Cape Peninsula University of Technology, Hexberg Road, Wellington Campus, Wellington 7655, Western Cape, South \\ Africa \\ (2) Department of Viticulture and Oenology, Stellenbosch University, Private Bag X1, Matieland 7062, South Africa \\ (3) Agricultural Research Council Infruitec-Nietvoorbij, Nietvoorbij, Stellenbosch, 7600, South Africa
}

Submitted for publication: March 2020

Accepted for publication: June 2020

Keywords: Pinking, pinking susceptibility, pinking assay

In the late 1960s, a phenomenon was discovered in white wines. It was noted that certain white wines turned pink in the bottle. This phenomenon was dubbed as pinking. Research was done on the pinking to establish its cause and effect. Analysis of $\mathrm{SO}_{2}, \mathrm{pH}$ and polyvinyl polypyrrolidone (PVPP) showed that a minimum of $45 \mathrm{mg} / \mathrm{L}$ of $\mathrm{SO}_{2}$ were needed for the wine not to be susceptible to pinking. Tests on the decrease in $\mathrm{pH}$ showed that there was no increase in pink colour with a decrease in $\mathrm{pH}$, which meant that monomeric anthocyanins were not the cause of pinking. Recent research claims that malvidin-3-Oglucoside is the most abundant monomeric anthocyanin found in pinked wines and could be the cause of pinking. This led to the theory that phenols contribute to pinking susceptibility, and this was accepted as fact in recent years. The establishment of a pinking assay in 1977 made the testing for pinking easier and cheaper for winemakers. The sales of PVPP increased as winemakers worked preventatively with their wine to decrease susceptibility to pinking. This review attempts to describe the history of pinking, the establishment of the assay, as well as to describe factors that could lead to pinking susceptibility in white wines.

\section{INTRODUCTION}

The first incidence of pinking in white wines was reported by Singleton and Esau in 1969. This led to a series of research articles on pinking from 1977 to 1983 by an Australian researcher, Dr Bob Simpson (1977a, 1977b, 1980a, 1980b; Simpson et al. 1982, 1983). This was followed by a research article on the use of polyvinyl polypyrrolidone (PVPP) by Lamuela-Raventós et al. (2001) and two articles on the presence of anthocyanins by Andrea-Silva et al. (2014) and Cosme et al. (2019). This literature review reports on the findings of Simpson and other researchers that investigated pinking susceptibility in white wines

Simpson (1977a) defines pinking as "the troublesome discolouration" that develops during the storage of white wines. He later adds that it develops over several days, but most likely after vinification or when the wine is no longer protected by a $\mathrm{CO}_{2}$ blanket. This led to the discovery that pinking occurs after contact with air (Simpson, 1980a). In 1982, Simpson stated that "white wines develop a pink colouration on exposure to air". Andrea-Silva et al. (2014) define pinking as "the appearance of a salmon-red blush in white bottled wines produced exclusively from white varieties". Therefore, a comprehensive definition of pinking could be established, as follows: Pinking, or oxidative pinking, is the slight discolouration of white wines from a pinkish to a salmon-red blush colour, affected by certain oenological processes before and after fermentation until storage during which the wine could come into contact with air.

Different cultivars have been reported to show some degrees of pinking susceptibility. In America, the white cultivars reported are Thompson Seedless, Semillon, Sauvignon blanc, Chardonnay and Chenin blanc (Tobe, 1983; Jones, 1989). In Australia, the cultivars reported to be prone to pinking are Muscat Gordo Blanco, Sultana, Palomino, Riesling, Doradillo and Crouchen (Simpson, 1977a). In Spain, the cultivars Sauvignon blanc, White Riesling, Chardonnay, Albariño, Macabeo, Xarelllo, Parellada, Garnatxa blanca (Grenache) and Verdejo were reported to have the potential to pink (Lamuela-Raventós et al., 2001). In Portugal, the cultivar reported was Síria (Andrea-Silva et al., 2014), and in the Czech Republic it was Pinot blanc, Pálava, Pinot Gris, Sauvignon blanc, Grüner Veltliner and Chardonnay (unpublished data). This is an extensive list of white cultivars. According to Simpson (1977a, 1977b), Tobe (1983), Jones (1989), LamuelaRaventós et al. (2001) and Andrea-Silva et al. (2014), the 
predominant cultivar that shows susceptibility to pinking is Sauvignon blanc. Winemakers must take note of this when producing Sauvignon blanc. Although these cultivars showed a tendency to pink, regional variations and yearly differences also influence the potential of these wines to pink (Simpson, 1977a; Andrea-Silva et al., 2014).

Wines made by winemaking practices such as cooling of the must, cold fermentation and the use of inert gasses (Ar, $\mathrm{N}_{2}$ and $\mathrm{CO}_{2}$ ) show higher susceptibility to pinking (Singleton \& Esau, 1969; Simpson et al., 1982). This led to the assumption that air contact or $\mathrm{O}_{2}$ increases pinking susceptibility (Simpson, 1980b). Other factors, such as storage temperatures, the presence of light, free $\mathrm{SO}_{2}$ content and the $\mathrm{pH}$ of the wine also play a role in pinking susceptibility (Simpson, 1977; Simpson et al., 1982). With the influence of light came the suggestion that wine must not be bottled in clear glass bottles, but rather in green or dark green bottles (Lamuela-Raventós et al., 2001). Anecdotal evidence also suggests that pinking does not affect the aroma or taste of the white wines (Simpson, 1980b; Lamuela-Raventós et al., 2001), but this has never been proven scientifically.

Simpson (1980b) states that there is "good evidence" that the compounds causing pinking have their origin in phenolics. This led to a worldwide belief that phenols cause pinking in white wines (Jacobson, 2006; Jackson, 2014, 2016), and that polyvinylpolypyrrolidone (PVPP) should be used for their removal (Lamuela-Raventos et al., 2001).

\section{MEASUREMENT OF PINK SUSCEPTIBILITY}

\section{Development of an assay}

Simpson (1977a, 1980b) did extensive studies on the pinking susceptibility of white wines and the analysis thereof. Spectrophotometric studies on normal white wines and wines with a visible pinking showed a distinctive bump over the $500 \mathrm{~nm}$ absorbency range (Figs $1 \& 2$ ). Therefore, because the greatest differences occurred at an optical density of 500 $\mathrm{nm}$, this wavelength was chosen as a suitable wavelength for testing for pinking susceptibility.

The absorbance of a normal white wine therefore will have a smooth curve at $500 \mathrm{~nm}$, but a white wine with a visible pink colouration will show an absorbency at $500 \mathrm{~nm}$. Thus, when white wine is tested for pinking susceptibility, two samples of the wine are taken. One will be the control and the other the treatment. The control sample is determined first at $500 \mathrm{~nm}$, followed by the pink induced sample. The difference between the two samples will show the pinking susceptibility of the wine. Simpson found that light-colour wines will show a pinking susceptibility of 5 (0.005 AU x 10 $0^{3}$, and darker coloured wines will have a pinking susceptibility above $10\left(0.01 \mathrm{AU} \times 10^{3}\right)$. With darker coloured white wines, Simpson meant wines that border on a more yellowish colour.

Wines that show a tendency to browning rather than pinking will show a greater absorbency at $420 \mathrm{~nm}$. At the wavelength of $420 \mathrm{~nm}$, there will be no interference from the pink colouration. Both pinking and browning therefore can be measured in white wines.

Simpson (1977a) prepared a $0.3 \%(\mathrm{w} / \mathrm{v})$ solution $(1 \mathrm{~mL}$ in $100 \mathrm{~mL}$ distilled water) of $30 \%(\mathrm{w} / \mathrm{v})$ hydrogen peroxide $\left(\mathrm{H}_{2} \mathrm{O}_{2}\right)$. He used increments of $0.05 \mathrm{~mL}$, starting from 0.05 $\mathrm{mL}$ in a $10 \mathrm{~mL}$ wine sample, and ending with $0.40 \mathrm{~mL}$ from this $0.3 \%(\mathrm{w} / \mathrm{v}) \mathrm{H}_{2} \mathrm{O}_{2}$ solution to end up with concentrations ranging from $15 \mathrm{mg} / \mathrm{L}$ to $120 \mathrm{mg} / \mathrm{L} \mathrm{H}_{2} \mathrm{O}_{2}$. For each wine tested, there were two samples, one of which was the control and the other one that received the $\mathrm{H}_{2} \mathrm{O}_{2}$ addition. These two samples of each wine were then kept in the dark for 24 hours before being analysed spectrophotometrically.

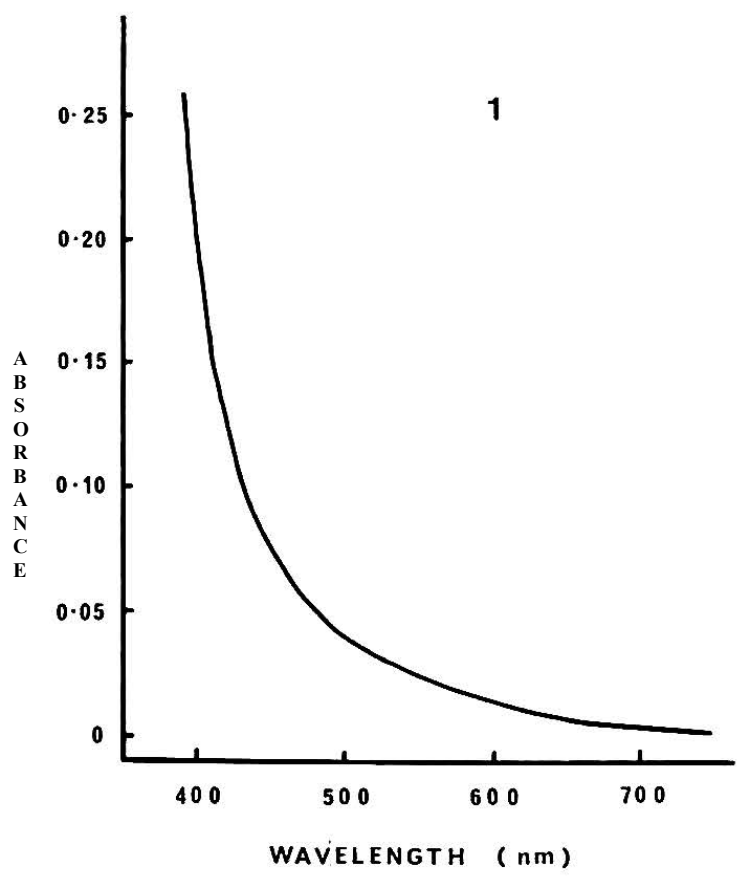

FIGURE 1

Spectrum of a wine showing no pinking (from Simpson, 1977). 


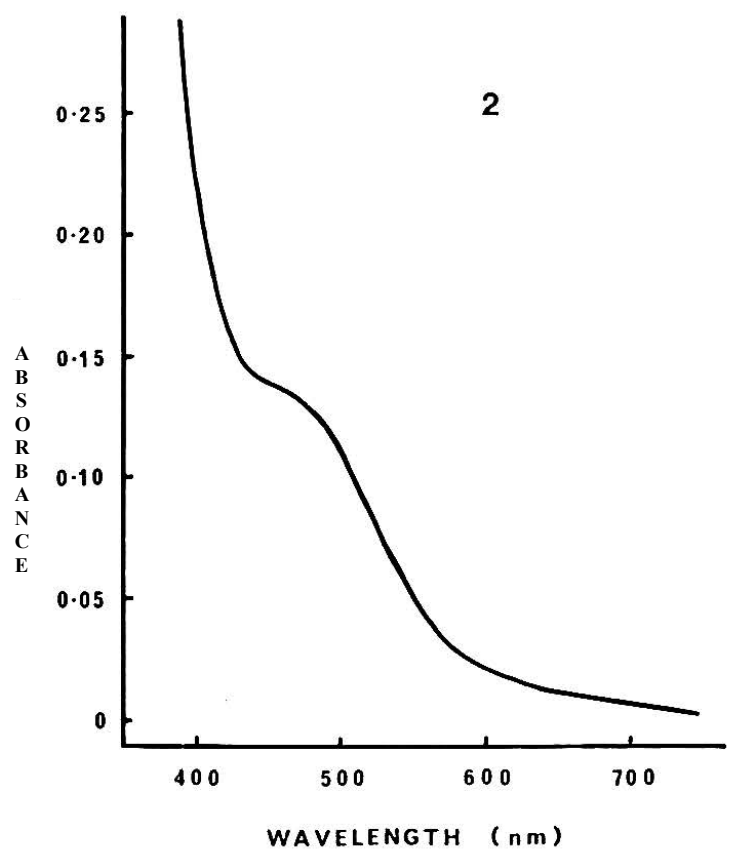

FIGURE 2

Spectrum of a wine showing pinking (from Simpson, 1977).

Simpson (1977a) found that the increase in pinking was linear up to 24 hours, reaching a peak at three days and then decreasing to 14 days. However, the reason for the shorter than three-day assay periods for pinking susceptibility used in the practice today could be that winemakers need to make a decision as quickly as possible and waiting three days for results is too long.

Simpson (1977a, 1980b) reports that, at a concentration of $75 \mathrm{mg} / \mathrm{L}(0.25 \mathrm{~mL}), \mathrm{H}_{2} \mathrm{O}_{2}$ shows the most consistent results. At $75 \mathrm{mg} / \mathrm{L}(0.25 \mathrm{~mL}) \mathrm{H}_{2} \mathrm{O}_{2}$, Simpson also found that $\mathrm{SO}_{2}$ did not influence the outcome, but at a concentration of 45 $\mathrm{mg} / \mathrm{L}(0.15 \mathrm{~mL}) \mathrm{H}_{2} \mathrm{O}_{2}$, the lack of $\mathrm{SO}_{2}$ or low concentrations of $\mathrm{SO}_{2}$ could influence the values and therefore give a false negative to the winemaker.

\section{Assays used in Australia, South Africa, America and Europe}

The assays for pinking and various approaches used in different parts of the world are described below. Although laboratories in winemaking countries use the assay established by Simpson (1977a), there are variations in different countries adapted to best suit their final objectives.

\section{Australia}

A 100 mL clear glass screw cap bottle is labelled as 'control' and another as 'test'. The 'control' bottle is filled with wine. Forty $\mathrm{mL}$ of the same wine is measured into the 'test' bottle, to which $0.5 \mathrm{~mL}$ of $0.3 \%(\mathrm{w} / \mathrm{v})$ hydrogen peroxide is added and mixed well. The 'test' sample is then placed in a dark cupboard at approximately $25^{\circ} \mathrm{C}$ overnight (about 12 hours). The degree of pinking of the 'test' wine is compared to that of the 'control'. In addition to visual assessment, spectral measures of the 'test' and 'control' wines can be performed at $520 \mathrm{~nm}$, which gives a quantitative comparison. In this case, the wines are filtered through a $0.45 \mu \mathrm{m}$ filter for assessment. A change greater than 0.050 at 500 nanometres (nm) between the control and treated sample indicates significant susceptibility to pinking (Australian Wine Research Institute [AWRI], 2020).

\section{South Africa}

According to the SASEV Methods of Analysis for Wine Laboratories (2002), a $0.072 \%(\mathrm{w} / \mathrm{v}) \mathrm{H}_{2} \mathrm{O}_{2}$ solution $(1.2$ $\mathrm{mL}$ of $30 \%(\mathrm{w} / \mathrm{v}) \mathrm{H}_{2} \mathrm{O}_{2}$ in $500 \mathrm{~mL}$ volumetric flask with distilled water) is used. A set of $5 \times 25 \mathrm{~mL}$ sample bottles are filled with wine and additions of $0,0.5,0.75,1.00$ and $1.25 \mathrm{~mL}$ of the $0.072 \%(\mathrm{w} / \mathrm{v})$ solution are done. The sample bottles are mixed gently and left for at least eight hours (the temperature and whether in a dark place or not are specified in the method). After eight hours, the samples are measured on a spectrophotometer at $500 \mathrm{~nm}$, zeroed with the control sample ( $0 \mathrm{~mL}$ of $\mathrm{H}_{2} \mathrm{O}_{2}$ added) and, if the optical density (OD) is above 0.05 , the wine is susceptible to pinking.

\section{America and Europe}

In both America and Europe, the method described by Simpson (1977a) is roughly followed (personnel communications). In America, $250 \mu \mathrm{L}$ of a $0.3 \%(\mathrm{w} / \mathrm{v}) \mathrm{H}_{2} \mathrm{O}_{2}$ solution is added to the wine sample, while in France $125 \mu \mathrm{L}$ of the $30 \%(\mathrm{w} / \mathrm{v})$ $\mathrm{H}_{2} \mathrm{O}_{2}$ is used. In both countries, the samples are kept in a dark cupboard for 24 hours. The specific method is not revealed by the laboratories and the personnel were not willing to part with all aspects of the methods. The spectrophotometer is zeroed with distilled water and both the control and treated samples are measured. The difference between these two is given as AU and, when the value is $\geq 0.05$, the wine is seen as having a pinking susceptibility. 


\section{Concluding remarks}

Simpson (1977a) reports that if the AU is above 5, the wine shows potential for pinking susceptibility. In his research work, he multiplied the absorbance unit (AU) by 1000 (x $10^{3}$ ) to get to a whole number. In all the methods, an AU of 0.05 (10 times higher than the 0.005 Simpson used in his original work) is used. It is not sure when this decision was made and for what reason, and this discrepancy has never been questioned.

The use of a $0.3 \%(\mathrm{w} / \mathrm{v}) \mathrm{H}_{2} \mathrm{O}_{2}$ solution in Australia and America has been reported, while in South Africa it is $0.072 \%(\mathrm{w} / \mathrm{v})$. In France, a $30 \%(\mathrm{w} / \mathrm{v})$ undiluted solution is added to the wine sample (Table 1). Different volumes of the $\mathrm{H}_{2} \mathrm{O}_{2}$ concentrations are used by the different countries (500 $\mu \mathrm{L}$ in $40 \mathrm{~mL}$ of wine sample, $250 \mu \mathrm{L}$ in $10 \mathrm{~mL}$ of wine sample, $1000 \mu \mathrm{L}$ in $25 \mathrm{~mL}$ of wine sample and $125 \mu \mathrm{L}$ in 10 $\mathrm{mL}$ of wine sample, respectively). The final concentrations of $\mathrm{H}_{2} \mathrm{O}_{2}$ in the treatment sample differ, but could easily be worked out with the formula $\mathrm{C}_{1} \mathrm{~V}_{1}=\mathrm{C}_{2} \mathrm{~V}_{2}$. This will lead to different sensitivity measurements and different absorbency units, and possibly different conclusions on whether or not a wine shows pinking susceptibility.

Another difference between the countries is that Australia uses a wavelength of $520 \mathrm{~nm}$, while South Africa and France use $500 \mathrm{~nm}$, as stated by Simpson (1977a). The reason for this could be that some countries scan through a wide range of spectra, i.e. 400 to $650 \mathrm{~nm}$, to determine the wavelength of maximum absorbance.

Simpson (1977a) originally used a $10 \mathrm{~mL}$ sample bottle for his experiments. This is also the case in America and France, while in Australia a $40 \mathrm{~mL}$ sample bottle is used (Iland et al., 2012). In South Africa, a $25 \mathrm{~mL}$ sample bottle is used (SASEV, 2002). The question arises if the addition of $\mathrm{H}_{2} \mathrm{O}_{2}$ from the different stock solutions will have an impact on the values for pinking susceptibility and regarding the pinking sensitivity of the wines. Would it then not be better to standardise to the original concentrations set by Simpson (1977a).

The above shows that there is no real standard for the testing of pinking susceptibility. In some cases, the waiting period is up to 24 hours, whereas in countries like South Africa it is reduced to eight hours of waiting. It is evident that there is a need to develop a standardised, shorter and more reliable method for the testing of pinking susceptibility. There is also no protocol prescribed by the International Organisation of Vine and Wine (OIV) on an assay for pinking.

\section{FACTORS INFLUENCING PINKING IN WHITE WINES}

In a series of articles published from 1980 to 1983, Simpson and co-workers discussed different factors that could contribute to the pinking susceptibility of white wines. The factors influencing pinking in white wine are discussed on the basis of these abovementioned articles and supplemented by other authors.

\section{The role of phenols}

Singleton and Esau (1969) discussed the possibility of colourless plant phenols turning pink in an acidic medium, like wine, when the colourless anthocyanogens turn into anthocyanidins. In 1977, Simpson also stated that the spectral and chemical properties of the pink wines tested indicated that the precursors could be phenolic in origin. This started the reasoning that the oxidation of phenols could lead to pinking.

Phenolics in wine are divided into two groups. These are the flavonoids, of which the flavan-3-ols are part, and the non-flavonoids, of which the hydroxycinnamic acids and hydroxybenzoic acids are part. The flavan-3-ols consist of catechin, epicatechin, epigallocatechin and epicatechingallate and are found mainly in the skins and pips of grapes (Monagas et al., 2005; Aron \& Kennedy, 2008; Piñeiro et al., 2012). The hydroxycinnamic and hydroxybenzoic acids are normally found in the fleshy parts of the grapes (Garrido \& Borges, 2013; Nel, 2018). Compounds that have an orthodiphenol grouping are highly reactive with dissolved oxygen (Garrido \& Borges, 2013) to form an ortho-quinone:

Ortho-diphenol $+\mathrm{O}_{2} \rightarrow$ ortho-quinone $+\mathrm{H}_{2} \mathrm{O}_{2}$

These ortho-quinones are very unstable because of their highly electrophilic nature and can react in a further three ways. Firstly, the ortho-quinone can form dimers or polymers if reacting with the nucleophilic parent. Secondly, the ortho-quinone can undergo further nucleophilic additions with other nucleophiles (amino acids, glutathione, and other phenols). Thirdly, the ortho-quinone can be reduced by other reducing species, like ascorbate and other phenols, to form ortho-diphenols (Fulcrand et al., 2006). All these non-enzymatic reactions are catalysed by $\mathrm{Fe}^{3+} / \mathrm{Fe}^{2+}$ or $\mathrm{Cu}^{3+} / \mathrm{Cu}^{2+}$. The oxidation of these phenols leads to the browning of white wines (Fulcrand et al., 2006; Garrido \& Borges, 2013; Rustioni, 2017). The cause of pinking is still speculative when it comes to phenols as causative agents.

TABLE 1

The differences in the assays used in South Africa, France, America and Australia

\begin{tabular}{lllll}
\hline & $\begin{array}{l}\mathbf{H}_{2} \mathbf{O}_{2} \text { from 30\% } \\
\text { stock solution }\end{array}$ & $\begin{array}{l}\text { Sample volume } \\
(\mathbf{m L})\end{array}$ & $\begin{array}{l}\mathrm{H}_{2} \mathbf{O}_{2} \text { added } \\
(\boldsymbol{\mu L})\end{array}$ & $\begin{array}{l}\text { Waiting period } \\
(\mathbf{h o u r s})\end{array}$ \\
\hline South Africa & $0.072 \%$ & 25 & 1000 & 8 \\
Australia & $0.3 \%$ & 40 & 500 & 12 \\
United States of America & $0.3 \%$ & 10 & 250 & 24 \\
France & $30 \%$ & 10 & 125 & 24 \\
\hline
\end{tabular}

The $\mathrm{H}_{2} \mathrm{O}_{2}$ solutions are all in $\%(\mathrm{w} / \mathrm{v})$ 
The attribution of several possible phenols (protocatechuic acid, catechin, epicatechin, caffeic acid, gallic acid, ethyl gallate, p-hydroxybenzoic acid, quercetin-3-rutinoside, quercitin-3-glucoside, quercetin-3-L-rhamnoside, quercetin3-D-galactoside, cis-coutaric acid, trans-coutaric acid, m-coutaric acid, p-coutaric acid, caftaric acid, ferulic acid, fertaric acid and coumaric acid), the implication of unstable flavonoid phenols (astilbin and engeletin) and the chemical degradation of some of these procyanidins in the presence of oxygen to form anthocyanogens may lead to the appearance of a pink colour (Tobe, 1983).

\section{The role of temperature}

Simpson (1977b) states that the development of the pink colour can generally be linked to the ingress of oxygen during winemaking processes. These processes are normally critical points in which oxygen uptake plays a role, such as pump-overs, filtration, bottling, etc. The solubility of oxygen increases with a decrease in temperature (Simpson, 1980b). Oxygen solubility in wine at room temperature and atmospheric pressure is about $6.0 \mathrm{~mL} / \mathrm{L}(8.6 \mathrm{mg} / \mathrm{L})($ Castellari et al., 2004; Waterhouse \& Laurie, 2006). This solubility increases by about $10 \%$ with a decrease in temperature (Waterhouse \& Laurie, 2006). Winemakers therefore should be careful about practices in which wine temperature is kept low and the chances for oxygen uptake are high, like crushing and destemming, pressing and pumping of wine at low temperatures.

\section{Light}

Simpson (1980a) suggests that when a wine pinks in the bottle it can be exposed to direct sun or UV light for about 10 minutes to reduce the pink discolouration. UV exposure might lead to reduced pinking, but can have other negative effects. To explain the chemistry behind UV exposure, Clark et al. (2011) show that $\mathrm{Fe}^{3+}$ and light have the potential to degrade wine compounds, like tartaric acid, 3-mercaptohexanol (3MH) and 3-mercapto hexylacetate (3MHA). Different coloured glass bottles have different degrading properties and protection against UV light and the degradation of compounds. The different coloured glass bottles, with their protective abilities in increasing order, are Flint < Arctic Blue $<$ French Green $<$ Antique Green glass (Dias et al., 2012). Light can also catalyse free radical reactions that are involved in the peroxidation step of autoxidation (Simpson, 1980b). The UV light furthermore promotes the browning of phenols in wine (Clark et al., 2011; Parish-Virtue et al., 2019). UV light has the ability to excite singlet oxygen, which is then able to diffuse over a large distance of $270 \mathrm{~nm}\left(2.7 \times 10^{-4} \mathrm{~mm}\right)$. The singlet oxygen molecule is electrophilic, as it has a completely vacant $2 p \pi$ orbital. Therefore, the singlet oxygen molecule can react with high e-density double bonds via a six-membered ring. This results in the formation of hydroperoxide radicals (HOO-) that again assist in autoxidation (Choe \& Min, 2009).

\section{Trace metals}

During non-enzymatic oxidation or chemical oxidation, $\mathrm{H}^{+}$ ions are transferred from a diphenol to an $\mathrm{O}_{2}$ to form $\mathrm{H}_{2} \mathrm{O}_{2}$, but these reactions can only take place in the presence of metal ion catalysers like $\mathrm{Fe}^{3+}$ and $\mathrm{Cu}^{2+}$. This process is mediated by the redox cycle, in which $\mathrm{Fe}^{3+} / \mathrm{Fe}^{2+}$ and $\mathrm{Cu}^{2+}$ / $\mathrm{Cu}^{+}$reduce oxygen to hydrogen peroxide (Oliveira et al., 2011). For this reason, knowledge of the iron and copper concentration of the wine is of utmost importance, as it can have a significant impact on the autoxidation of the wine.

\section{$\mathrm{SO}_{2}$ concentration of the wine}

During a study done by Simpson (1977a) on the effect of $\mathrm{SO}_{2}$ on pinking susceptibility, he reduced the $\mathrm{pH}$ of a range of wines to $\mathrm{pH} 1$. Sparging of the wine with nitrogen expelled the $\mathrm{SO}_{2}$ from the wine. Simpson then adjusted the $\mathrm{pH}$ of the wines back to their normal states and added $\mathrm{SO}_{2}$ in potassium metabisulphite form up to a free $\mathrm{SO}_{2}$ of $60 \mathrm{mg} / \mathrm{L}$. Two concentrations of $\mathrm{H}_{2} \mathrm{O}_{2}$, viz. $15 \mathrm{~mL} / \mathrm{L}$ and $75 \mathrm{~mL} / \mathrm{L}$, were added to the wines and the pinking susceptibility was tested. With the lower concentration $(15 \mathrm{~mL} / \mathrm{L})$ of $\mathrm{H}_{2} \mathrm{O}_{2}$, the pinking susceptibility was reduced proportionally with the increase in free $\mathrm{SO}_{2}$. With the higher concentration of $\mathrm{H}_{2} \mathrm{O}_{2}$ $(75 \mathrm{~mL} / \mathrm{L})$, there was a reduction in pinking at a free $\mathrm{SO}_{2}$ of $40 \mathrm{mg} / \mathrm{L}$. The amount of free $\mathrm{SO}_{2}$ (concentration of about $40 \mathrm{mg} / \mathrm{L}$ ) in the wine was sufficient to react with $\mathrm{H}_{2} \mathrm{O}_{2}$ to form an $\mathrm{HSO}_{3}{ }^{-}$anion. This will also be sufficient to prevent pinking in white wines (Simpson, 1977a).

\section{Ascorbic acid addition as an antioxidant}

Ascorbic acid is a very strong antioxidant as it reacts effectively with $\mathrm{O}_{2}$ in the wine (Simpson, 1980a, 1980b). The $\mathrm{H}_{2} \mathrm{O}_{2}$, formed from transferring an $\mathrm{H}^{+}$ion to an $\mathrm{O}_{2}$ from ascorbic acid, is also a very strong oxidising agent (Bradshaw et al., 2004, 2011; Barril et al., 2016) and therefore the concentration of free $\mathrm{SO}_{2}$ in the wine needs to be at least $40 \mathrm{mg} / \mathrm{L}$ (Simpson, 1977a). Ascorbic acid is one of the agents that works very well in preventing pinking in white wines. The addition of ascorbic acid prior to bottling may also keep the wine safe against oxidative browning in the bottle (Gibson, 2006). But there could also be a downside to the addition of ascorbic acid as it may also decrease the shelf life of the wine, with the risk of oxidative browning and even pinking (Bradshaw et al., 2011; Barril et al., 2016). Bradshaw et al. (2004) found that the molar ratio of ascorbic acid to $\mathrm{SO}_{2}$ must be 1:1.7 to prevent oxidative browning and pinking in wines.

\section{Wine pH}

The equilibrium of molecular $\mathrm{SO}_{2}$, bisulphite and sulphite ions in wine is $\mathrm{pH}$ dependent. A sulphite anion attached on the C-4 position of the anthocyanin transforms it into a colourless form. This means that, at a lower $\mathrm{pH}$, more molecular $\mathrm{SO}_{2}$ is available for the protection of the wine against oxidation (Simpson, 1980b; Abramovič et al., 2015). Simpson (1977a) tested the influence of $\mathrm{pH}$ on pinking. Wine with a known pinking susceptibility was used to provide a $\mathrm{pH}$ range from 2.75 to 4.00 . Pinking values were then obtained four hours after the addition of $75 \mathrm{mg} / \mathrm{L} \mathrm{H}_{2} \mathrm{O}_{2}$. In a second test, samples were acidified to a $\mathrm{pH}$ of 1 and assayed for pinking. No significant differences were obtained in the $\mathrm{pH}$ range, as well as for the acidification test. This led Simpson to believe that the compound causing pinking is not a flavylium salt or its glucosides (anthocyanins). This 
was confirmed by Tobe (1983), who used seven cultivars made from grapes in an experimental wine cellar in 1981, and Jones (1989), who made wine in three consecutive years (1985 to 1987). The wines that were made were treated specially for the experiments planned. Although true for monomeric anthocyanins, polymeric anthocyanins are more resistant to $\mathrm{SO}_{2}$ bleaching and $\mathrm{pH}$ changes (Somers, 1971; Andrea-Silva et al., 2014). During ageing and/or maturation, a polymerisation of anthocyanins takes place at the C-8 and C-6 positions, forming anthocyanin-tannin condensation reactions (Monagas et al., 2005). These reactions lead to a stable polymeric anthocyanin, which therefore is resistant to decolouration by $\mathrm{SO}_{2}$ and to $\mathrm{pH}$ changes (Somers, 1971).

\section{TREATMENT OF PINKING SUSCEPTIBILITY OF WHITE WINES}

Lamuela-Raventós et al. (2001) did a series of experiments to find the best product to remove the precursors for pinking susceptibility in white wines. Wines were divided into four lots, control wine; wine with $1 \mathrm{~g} / \mathrm{L}$ PVPP, wine with $1 \mathrm{~g} / \mathrm{L}$ PVPP $+0.5 \mathrm{~g} / \mathrm{L}$ bentonite and wine with $1 \mathrm{~g} / \mathrm{L}$ PVPP $+15 \mathrm{mg} / \mathrm{L}$ ascorbic acid. Wine treated with $1 \mathrm{~g} / \mathrm{L}$ PVPP reduced pinking by $74 \%$, the wine with $1 \mathrm{~g} / \mathrm{L}$ PVPP +0.5 $\mathrm{g} / \mathrm{L}$ bentonite reduced pinking with $90 \%$, and the wine with $1 \mathrm{~g} / \mathrm{L}$ PVPP $+15 \mathrm{mg} / \mathrm{L}$ ascorbic acid reduced pinking with $98 \%$. However, after 20 days the capacity of ascorbic acid + PVPP to reduce pinking decreased to the same levels as that of PVPP + bentonite. Tobe (1980) investigated the removal of precursors by bentonite and PVPP. He found initially observed decreases in total phenols by bentonite fining, to be ineffective after applying the Freundlich equation. PVPP was more favourable in removing the total phenols. LamuelaRaventós et al. (2001) added various concentrations of ascorbic acid to a wine, i.e. $0,15,30,45$ and $100 \mathrm{mg} / \mathrm{L}$. At $30 \mathrm{mg} / \mathrm{L}$ pinking was reduced, however, at $45 \mathrm{mg} / \mathrm{L}$ pinking was completely prevented. This showed that ascorbic acid is a good agent to prevent pinking susceptibility in white wine, but it could lead to oxidative browning after an extended period (Lamuela-Raventós et al., 2001).

\section{ALTERNATIVE EXPLANATIONS TO PINKING}

Andrea-Silva et al. (2014) report the compound to cause pinking susceptibility in Siria wines to be malvidin-3-Oglucoside, which was the most abundant anthocyanin tested. Siria is a Portuguese cultivar, a widely planted Iberian variety also known as Roupeiro, Doña Blanca and Cigüente. The wine is aromatic but oxidises easily (Robinson et al., 2012).

Andrea-Silva et al. (2014) mention that the wine used for their experiments pinked naturally. After pinking, 0.8 $\mathrm{g}$ of PVPP was added. The suspension was then filtered through a cheesecloth and washed with $100 \mathrm{~mL}$ of water and $100 \mathrm{~mL}$ of ethanol (95\%). Thereafter, the PVPP was loaded into an empty SPE cartridge and eluted with acetonitrile and acetone, an aqueous solution of $1 \% \mathrm{HCl}$, ethanol and 0.1 $\mathrm{M} \mathrm{NH}_{3}$ in ethanol. Each fraction was kept separate. After evaporation and reconstitution with $0.2 \mathrm{~mL}$ of methanol and water, the samples were loaded onto an HPLC. The main compound found was malvidin-3-O-glucoside. Andrea-Silva et al. (2014) also established that the minimum amount of total anthocyanin must be $0.3 \mathrm{mg} / \mathrm{L}(300 \mu \mathrm{g} / \mathrm{L})$ to turn the wine a visible pink colour. This experiment was repeated in 2019 (Cosme et al., 2019). Arapitsas et al. (2015) analysed grapes of Sauvignon blanc, Chardonnay and Riesling using a UPLC-MS/MS. They found measurable amounts of malvidin-3-O-glucoside, as well as carboxypyranomalvidin3-O-glucoside (A-type vitisin) and pyranomalvidin-3-Oglucoside (B-type vitisin). The amounts were $55.44 \mu \mathrm{g} / \mathrm{kg}$, $37.05 \mu \mathrm{g} / \mathrm{kg}$ and $38.99 \mu \mathrm{g} / \mathrm{kg}$, respectively, for Sauvignon blanc, Chardonnay and Riesling (Arapitsas et al., 2015).

In genetic analyses for anthocyanins in red and white grapes, six genes were determined in the flavonoid biosynthetic pathway. Some genes were expressed in all grapes, even where little or no anthocyanins accumulated, but an expression of the gene encoding a UDP glucoseflavonoid 3-o-glucosyl transferase (UFGT) was only detected in red grapes that synthesised anthocyanins. The analysis of the white grapes indicated that the UFGT gene was present but was not expressed (Boss et al., 1996). External environmental conditions and vineyard practices therefore can switch on these genes to start the anthocyanin metabolic pathways (Boss et al., 1996).

The original researcher on pinking, Dr Bob Simpson, reported that phenols (flavonoid and non-flavonoids) and not anthocyanins are the causative compound. Research on pinking in wine is thus far from over and more evidence is needed to find the colour-forming compound.

\section{REFERENCES}

Abramovič, H., Košmerl, T., Ulrih, N.P. \& Cigic, B., 2015. Contribution of $\mathrm{SO}_{2}$ to antioxidant potential of white wine. Food Chem. 174, 147-153.

Andrea-Silva, J., Cosme, F., Ribeiro, L.F., Moreira, A.S.P., Malheiro, A.C., Coimbra, M.A., Domingues, M.R.M. \& Nunes, F.M., 2014. Origin of the pinking phenomenon of white wines. J. Agric. Food Chem. 62, 5651-5659.

Arapitsas, P., Oliveira, J. \& Mattivi, F., 2015. Do white grapes really exist? Food Res. Int. 69, 21-25

Aron, P.M. \& Kennedy, J.A., 2008. Flavan-3-ols: Nature, occurrence and biological activity. Mol. Nutr. Food Res. 52, 79-104.

Australian Wine Research Institute (AWRI), 2020. Pinking. Available from https://www.awri.com.au/industry_support/winemaking_resources/ frequently_asked_questions/pinking/(accessed October 2019).

Barril, C., Rutledge, D.N., Scollary, G.R. \& Clark, A.C., 2016. Ascorbic acid and white wine production: A review of beneficial versus detrimental impacts. Aust. J. Grape Wine Res. 22, 169-181.

Boss, P.K., Davies, C. \& Robinson, S.P., 1996. Anthocyanin composition and anthocyanin pathway gene expression in grapevine sports differing in berry skin colour. Aust. J. Grape Wine Res. 2, 163-170.

Bradshaw, M.P., Barril, C., Clark, A.C., Prenzler, P.D. \& Scollary, G.R., 2011. Ascorbic acid: A review of its chemistry and reactivity in relation to a wine environment. Crit. Rev. Food Sci. 51, 479-498.

Bradshaw, M.P., Scollary, G.R. \& Prenzler, P.D., 2004. Examination of the sulfur dioxide-ascorbic acid anti-oxidant system in a model white wine matrix. J. Sci. Food Agric. 84, 318-324.

Castellari, M., Simonato, B., Tornielli, G.B., Spinelli, P. \& Ferrarini, R., 2004. Effects of different enological treatments on dissolved oxygen in wines. Ital. J. Food Sci. 3(16), 387-397. 
Choe, E. \& Min, D.B., 2009. Mechanisms of antioxidants in the oxidation of foods. Compr. Rev. Food Sci. F. 8, 345-358.

Clark, A.C., Dias, D.A., Smith, T.A., Ghiggino, K.P. \& Scollary, G.R., 2011. Iron(III) tartrate as a potential precursor of light-induced oxidative degradation of white wine: Studies in a model wine system. J. Agric. Food Chem. 59, 3575-3581.

Cosme, F., Andrea-Silva, J., Filipe-Ribeiro, L., Moreira, A.S.P., Malheiro, A.C., Coimbra, M.A., Domingues, M.R.M. \& Nunes, F.M., 2019. The origin of pinking phenomena in white wines: An update. 41st World Congress of Vine and Wine. BIO Web of Conferences 12, 1-5.

Dias, D.A., Smith, T.A., Ghiggino, K.P. \& Scollary, G.R., 2012. The role of light, temperature, and wine bottle colour on pigment enhancement in white wine. Food Chem. 135, 2934-2941.

Fulcrand, H., Dueñas, M., Salas, E. \& Cheynier, V., 2006. Phenolic reactions during winemaking and aging. Am. J. Enol. Vitic. 57(3), 289-297.

Garrido, J. \& Borges, F., 2013. Wine and grape polyphenols - A chemical perspective. Food Res. Int. 54, 1844-1858.

Gibson, R., 2006. Ascorbic acid - friend or foe? 35th Annual New York Wine Industry Workshop, 2006, New York.

Iland, P., Bruer, N., Edwards, G., Caloghiris, S. \& Wilkes, E., 2012 (2nd ed). Chemical analysis of grapes and wine: Techniques and concepts. Patrick Iland Wine Promotions Pty Ltd., Adelaide, Australia.

Jackson, R.S., 2014. Post-fermentation treatments and related topics. In: Wine science: Principles and applications. Academic Press, Elsevier, pp. $418-521$

Jackson, R.S., 2016 (3rd ed). Wine tasting: A professional handbook. Academic Press, Ontario, Canada.

Jacobson, J.L., 2006. Introduction to wine laboratory practices and procedures. Springer, United States of America.

Jones, T., 1989. Pinking of white table wines: Further studies. Unpublished Master of Science thesis, University of California, Davis, CA, USA.

Lamuela-Raventós, R.M., Huix-Blanquera, M. \& Waterhouse, A.L., 2001. Treatments for pinking alteration in white wines. Am. J. Enol. Vitic. 52(2), 156-158.

Monagas, M., Bartolomé, B. \& Gómez-Cordovés, C., 2005. Updated knowledge about the presence of phenolic compounds in wine. Crit. Rev. Food Sci. 45, 85-118.

Nel, A.P., 2018. Tannins and anthocyanins: From their origin to wine analysis - A review. S. Afr. J. Enol. Vitic. 39(1), 1-19.
Oliveira, C.M., César, A.C., Ferreira, S., De Freitas, V. \& Silva, A.M.S., 2011. Oxidation mechanisms occurring in wines. Food Res. Int. 44(5), 1115-1126.

Parish-Virtue, K., Herbst-Johnstone, M., Bouda, F. \& Fedrizzi, B., 2019. The impact of postharvest ultra-violet light irradiation on the thiol content of Sauvignon blanc grapes. Food Chem. 271, 747-752.

Piñeiro, Z., Canepa, D., Palma, M. \& Barroso, C.G., 2012. Evolution of grape seed flavan-3-ols during ripening of different grape cultivars. Int. J. Food Sci. Tech. 47, 40-46.

Robinson, J., Harding, J. \& Vouillamoz, J., 2012. Wine grapes: A complete guide to 1,368 vine varieties, including their origins and flavours. Harper Collins, London.

Rustioni, L., 2017. Oxidized polymeric phenolics: Could they be considered photoprotectors? J. Agric. Food Chem. 65, 7843-7846.

SASEV, 2002. Methods of analysis for wine laboratories. South African Wine Laboratory Association, Stellenbosch.

Simpson, R.F., 1977a. Oxidative pinking in white wines. Vitis 16, 286-294

Simpson, R.F., 1977b. Pinking in Australian white table wines. Austr. Wine Brew. Spirit Rev. November, 56-58.

Simpson, R.F., 1980a. Some aspects of oxidation and oxidative browning in white table wines. Austr. Grapegrower \& Winemaker January, 20-21.

Simpson, R.F., 1980b. Some aspects of oxidative pinking of white wines. Austr. Grapegrower \& Winemaker, December, 12-13.

Simpson, R.F., Bennett, S.B. \& Miller, G.C., 1983. Oxidative pinking of white wines: A note on the influence of sulphur dioxide and ascorbic acid. Food Tech. Austr. 35(1), 34-36.

Simpson, R.F., Miller, G.C. \& Orr, G.L., 1982. Oxidative pinking of white wines: Recent observations. Food Tech. Austr. 34(1), 44-47.

Singleton, V.L. \& Esau, P., 1969. Phenolic substances in grapes and wine, and their significance. Adv. Food Res. Suppl. 1, 1-261.

Somers, T.C., 1971. The polymeric nature of wine pigments. Phytochemistry 10(9), 2175-2186

Tobe, S.J., 1983. Pinking in table wines from white grapes. Unpublished MSc thesis, University of California, Davis, USA.

Waterhouse, A.L. \& Laurie, V.F., 2006. Oxidation of wine phenolics: A critical evaluation and hypotheses. Am. J. Enol. Vitic. 57(3), 306-313. 